\title{
Psychosocial factors and physical activity as predictors of fruit and vegetable intake in college students
}

\author{
Fatores psicossociais e atividade física como \\ preditores do consumo de frutas, legumes \\ e verduras em estudantes universitários
}

Rafael Miranda TASSITANO ${ }^{1}$

Clarice Maria de Lucena MARTINS²

Poliana Coelho CABRAL ${ }^{3}$

Jorge MOTA ${ }^{4}$

Maria Cecíla Marinho TENÓRIO'

Giselia Alves Pontes da SILVA ${ }^{5}$

\section{A B S T R A C T}

\section{Objective}

To analyze whether psychosocial factors and physical activity are predictors of fruit and vegetable intake in young adults attending college.

\section{Methods}

This cross-sectional study included a representative sample of students from a public university in the Brazilian Northeast $(n=717)$. Fruit and vegetable intake was measured by a Food Frequency Questionnaire containing 21 items. The psychosocial factors for behavior change, measured by a questionnaire, were: behavior change strategy, self-efficacy, perceived barriers and facilitators in decision making, and social support. The level of

\footnotetext{
1 Universidade Federal Rural de Pernambuco, Departamento de Educação Física. R. Dom Manoel de Medeiros, s/n., Dois Irmãos, 52171-900, Recife, PE, Brasil. Correspondência para/Correspondence to: RM TASSITANO. E-mail: <rafael.tassitano@gmail.com>.

2 Universidade Federal da Paraíba, Centro de Ciências da Saúde, Departamento de Educação Física. João Pessoa, PB, Brasil.

3 Universidade Federal de Pernambuco, Centro de Ciências da Saúde, Departamento de Nutrição. Recife, PE, Brasil.

${ }^{4}$ Universidade do Porto, Faculdade de Desporto. Porto, Portugal.

5 Universidade Federal de Pernambuco, Centro de Ciências da Saúde, Departamento de Saúde Materno Infantil. Recife, PE, Brasil.

Article based on the doctoral dissertation of R TASSITANO entitled "Impacto de uma intervenção para o aumento da atividade física e consumo de frutas, legumes e verduras em estudantes universitários: ensaio clínico randomizado". Universidade Federal de Pernambuco; 2013.
} 
physical activity was measured by the International Physical Activity Questionnaire. Multiple linear regression was the intake prediction model using a significance level of $5 \%(p<0.05)$.

\section{Results}

The median fruit and vegetable intake was 2.0 servings/day. In adjusted analysis, behavior change strategy $\left(R^{2}=0.31\right)$, self-efficacy $\left(R^{2}=0.03\right)$, friends' support $\left(R^{2}=0.02\right)$, and physical activity $\left(R^{2}=0.03\right)$ explained $39 \%$ of the fruit and vegetable intake variance in men. Behavior change strategy $\left(R^{2}=0.03\right)$, self-efficacy $\left(R^{2}=0.13\right)$, perceived barriers $\left(R^{2}=0.08\right)$, and physical activity $\left(R^{2}=0.02\right)$ explained $26 \%$ of the fruit and vegetable intake variance in women. Fruit and vegetable intake would increase by one serving for every extra 35 and 47 minutes of physical activity men and women, respectively, practice a day.

\section{Conclusion}

The main predictors of fruit and vegetable intake are behavior change strategies, self-efficacy, and physical activity.

Keywords: Food consumption. Motor activity. Students.

\section{R E S U M O}

\section{Objetivo}

Analisar os fatores psicossociais e a atividade física como preditores no consumo de frutas, legumes e verduras em adultos jovens, estudantes universitários.

\section{Métodos}

Estudo transversal com uma amostra representativa de estudantes de uma universidade pública do Nordeste ( $n=717)$. O consumo de frutas, legumes e verduras foi medido por um Questionário de Frequência Alimentar composto por 21 itens. Os fatores psicossociais para a mudança de comportamento, medidas através de questionário, foram: estratégia de mudança de comportamento, autoeficácia, percepção das barreiras e facilitadores e apoio social. A atividade física foi medida pelo Questionário Internacional de Atividade Física. Utilizou-se a regressão linear múltipla para o modelo de predição do consumo, sendo adotado um $p<0,05$.

\section{Resultados}

A mediana do consumo de frutas, legumes e verduras foi de 2,0 porções/dia. Na análise ajustada, estratégia de mudança $\left(R^{2}=0,31\right)$, autoeficácia $\left(R^{2}=0,03\right)$, apoio dos amigos $\left(R^{2}=0,02\right)$ e atividade física $\left(R^{2}=0,03\right)$ explicaram $39 \%$ da variância do consumo entre os homens. Para as mulheres, as variáveis foram estratégia de mudança $\left(R^{2}=0,03\right)$, autoeficácia $\left(R^{2}=0,13\right)$, barreiras percebidas $\left(R^{2}=0,08\right)$ e atividade física $\left(R^{2}=0,02\right)$, explicando $26 \%$ da variância do consumo. O consumo de frutas, legumes e verduras aumentaria em uma porção com o incremento de 35 minutos de atividade física por dia para os homens e 47 minutos para as mulheres.

\section{Conclusão}

Os principais preditores do consumo de frutas, legumes e verduras foram as estratégias para a mudança de comportamento, autoeficácia e atividade física.

Palavras-chave: Consumo de alimentos. Atividade motora. Estudantes.

\section{INTRODUCTION}

Adequate fruit and vegetable intake, essential for a healthy diet, is associated with weight maintenance and lower risk of developing chronic non-communicable diseases ${ }^{1}$. The World Health Organization (WHO) recommends an intake of at least $400 \mathrm{~g}$ per day or at least five servings per day ${ }^{1}$. Despite the recognition of its benefits and encouragement actions introduced in the last decades, most people throughout the world do not consume the minimum recommended amount ${ }^{1,2}$. According to the Brazilian Family Budget Survey 2008/2009, the recommended intake of $400 \mathrm{~g}$ per day is not reached even by the ninetieth percentile of the Brazilian fruit and vegetable intake ${ }^{3}$.

Although, on the one hand, evidence of the environmental, economic, social, and 
demographic determinants of fruit and vegetable intake are well documented in the literature ${ }^{4,5}$, on the other, understanding how individuals establish and maintain healthy behaviors has been the focus of studies in the last decades ${ }^{6}$. Understanding the psychosocial determinants is key for the development of more effective behavioral interventions to increase fruit and vegetable intake ${ }^{7,8}$. There is evidence that self-efficacy, beliefs, values, expectations, perceived barriers and facilitators in decision making, and influence of parents and friends predict behavior, which is influenced by society and the environment ${ }^{7-9}$. However, systematic reviews have indicated that the proposed prediction models explain only about $30 \%$ of the intake $e^{7-9}$.

Another two aspects still require elucidation: first, the manner in which this process occurs in different social contexts and life stages ${ }^{9}$. For example, even though the transition from adolescence to adulthood and college is a critical period for adopting health behaviors ${ }^{10}$, few studies have included this population group ${ }^{6-8}$, especially in Brazil. Second, the manner in which other health behaviors can influence intake. Health behaviors tend to coexist ${ }^{6,11}$, and fruit and vegetable intake has been associated with physical activity $^{12-14}$. This is clear in $\mathrm{WHO}$ documents that provide health-promoting strategies integrating physical activity and a healthy diet ${ }^{15,16}$.

Since the 1990s, researchers in the University of San Diego/United States of America have been conducting studies that use the social cognitive theory ${ }^{17}$ and transtheoretical model ${ }^{18}$ to change health behaviors and lifestyles. They have developed, validated, and used in studies with diverse epidemiological designs the constructs of these theories for many health behaviors, including physical activity and fruit and vegetable intake ${ }^{13,14,19}$. Despite this realization, in most studies physical activity did not predict fruit and vegetable intake in an explanatory model, characterizing a gap in the direction of this relationship. In Brazil only one study with adults had this objective ${ }^{20}$.

Thus, the objective of this study is to investigate whether psychosocial factors and physical activity are predictors of fruit and vegetable intake in young adults attending a public university in the Brazilian Northeast.

\section{METHODS}

The target population consisted of students attending the Universidade Federal Rural de Pernambuco (UFRPE) $(n=12,451)$. Males and females aged 18 to 24 years were eligible. The exclusion criteria were: a) physical disability; b) mental disability; c) interchange students (Brazilians or foreigners), and d) students enrolled in distance learning courses and attending any campus other than the main campus. A total of 7,287 students met these criteria.

The minimum sample size was calculated by the calculator Gpower 3.1 (Heinrich-Heine Universität Düsseldorf, Düsseldorf, Germany) ${ }^{21}$ using the following parameters: $\alpha$ of 0.05 ; power of $80 \%$; effect size $\left(f^{2}\right)$ of 0.1 ; and eight predictors. Therefore, the sample should have 335 students. However, we chose to separate the analyses by gender, so the sample was multiplied by two, totaling 670 students. The proportions of males and females in each program and class schedule (morning, afternoon, evening) were respected for the sample to be similar to the target population. Students enrolled in morning and afternoon class schedules were grouped in a single category, day class schedule. Two-stage cluster sampling was used. In the first stage, all programs were eligible for the study. The stratification criterion was the density of students in each program and class schedule. In the second stage, all students (smallest sampling unit) of each program were considered eligible for the study. The students were selected by simple random sampling, and the stratification criterion was the density of males and females by class schedule and year of each program. The software Randomizer used random 
numbers to select the programs. The software is available at www.randomizer.org.

A three-section questionnaire was used for data collection: measurement of fruit and vegetable intake and psychosocial factors for behavior change; measurement of physical activity; and collection of demographic, socioeconomic, and institutional data. Fruit and vegetable intake was measured by a Food Frequency Questionnaire (FFQ) ${ }^{22}$. Only the fruit and vegetable intake section was used, consisting of the 21 fruit and vegetable most frequently consumed by Brazilians, 11 vegetables and 10 fruits. A pilot study showed that this procedure had good reproducibility ( $r=0.56-0.83)$. The answer options were numbers of fruit and vegetable servings consumed per day. The instrument defined the amount of each food contained in one serving. This initiative improves the accuracy of the collected data ${ }^{23}$. The daily fruit and vegetable intake was given by adding the number of servings of each item consumed throughout the day.

The study psychosocial factors that compose the social cognitive theory ${ }^{17}$ and the transtheoretical model ${ }^{18}$ were behavior change strategies, self-efficacy, perceived facilitators and barriers in decision making, and support of parents and friends. The scales were validated in Brazil $^{24}$ and abroad $^{19}$, and used in empirical studies ${ }^{12,13}$

The scale of behavior change strategy consisted of 15 items that investigated actions, thoughts, activities, strategies, and feelings that individuals may use for changing behavior and maintaining a new behavior $(\alpha=0.88$ [0.82-0.93] $)^{24}$. The answers were in the form of a five-point Likert scale as follows: never $=1$; almost never $=2$; sometimes $=3$; frequently $=4$; and many times $=5$. The final score was given by adding the answers.

Cognitive and motivational aspects are needed for acquiring and maintaining new behaviors. The said aspects were assessed by five questions on perceived facilitators $(\alpha=0.77$
[0.63-0.86] $)^{24}$ and five questions on perceived barriers $(\alpha=0.83 \text { [0.73-0.90] })^{24}$. The five-point Likert scale indicated how important each situation is: not important $=1$; slightly important $=2$; more or less important $=3$; very important $=4$; extremely important $=5$. The final scores were given by adding the answers of the respective constructs.

Self-efficacy relates to how confident individuals feel that they can perform or acquire a given behavior despite the various existing barriers. There are seven situational items on how individuals perceived internal cognitive issues (tiredness, stress, etc.) and external environment issues (weather, climate, etc.) $(\alpha=0.83 \text { [0.72-0.90] })^{24}$. The available answers as a five-point Likert scale were: absolutely not $=1$; probably not $=2$; indifferent $/$ neutral $=3$; probably $=4$; and absolutely $=5$. The final score was given by adding the answers.

Friends' support, consisting of three items $(\alpha=0.85[0.76-0.91])^{24}$, is a construct similar to parental support $(\alpha=0.79[0.67-0.88])^{24}$. They represent the support and encouragement that determine behavior. The available answers as a five-point Likert scale were: never $=1$; one to two days $=2$; three to four days $=3$; five to six days $=4$; and every day $=5$. The options were added to determine the respective scores.

The level of physical activity was determined by the International Physical Activity Questionnaire ${ }^{25}$. The instrument considers the time (in minutes per day) spent on moderate to intense physical activity in a normal week in four categories (leisure, work, house chores, and commuting). The pilot study indicated good questionnaire reproducibility for this item $(r=0.67-0.91)$.

The other sample-characterization variables were divided into social and demographic (gender, age, marital status), economic (socioeconomic level ${ }^{26}$ and employment status) and institutional (class schedule and program year). The answer categories were: gender (male and female); age (on the visit day); socioeconomic class (A, B, C, D, 
and E); employment status (no and yes); class schedule (day and evening); and program year the student was attending at the time of the interview.

Data were collected from October 22 to November 22, 2010, by 8 interviewers, undergraduate students attending a class on introduction to science in the programs of physical education (UFRPE) and nutrition (Universidade Federal do Pernambuco [UFPE]). The students received training to standardize the data collection procedures. The training lasted eight hours and included information about the study themes, and the theoretical and applied parts of the operational procedures. The interviews were conducted individually in a classroom and lasted 25 to 35 minutes.

The software EpiData (EpiData Association, Odense, Denmark) (version 3.1) performed the final data tabulation, and the software Sciences Statistical Package for the Social Sciences (SPSS Inc., Chicago, Illinois, United States) version 17.0 treated the data. The items that compose the constructs were added to obtain a score for each psychosocial factor. All continuous variables and residuals in the regression model were tested for normality. Univariate analysis of central tendency, dispersion (continuous variables), and frequency (discrete variables) were conducted.

Analysis of Variance (Anova) investigated the gender-related differences in behavior and psychosocial factors. A correlation matrix was generated between the psychosocial, physical activity, and fruit and vegetable intake variables to verify the existence of multicollinearity and singularity. Then, a prediction model for fruit and vegetable intake was established by conducting multiple regression analysis for men and women separately, and adjusting for the other independent variables. Although fruit and vegetable intake did not differ between genders, the decision to construct two models was based on the male and female differences in some psychosocial factors and physical activity. The variables were added simultaneously to the model to estimate the explanatory variance of each predictor (partial $R^{2}$ ) and the global variance of the model. Inclination (b), intercept (a), standard error, and $\beta$ value were also estimated. The models were adjusted for social, demographic, and institutional variables. All bivariate and multivariate analyses used $p<0.05$.

This cross-sectional study was approved by the Human Research Ethics Committee of the UFPE under Protocol $n^{\circ}$ CEP/CCS/UFPE 313/2010. All stages of the study complied with the regulations established by the Guidelines and Norms for the Regulation of Human Research.

\section{RE S U L T S}

The data collection locations (classrooms) of the chosen program years contained 851 students; 102 were older than 24 years, and 32 refused to participate in the study, so 717 students (55.9\% were females) were effectively interviewed. The mean age and standard deviation of the sample was $20.6 \pm 1.9$ years. Most (95.4\%) students were single, $67.5 \%$ attended morning classes, $64.6 \%$ did not work, $76.7 \%$ were freshmen or sophomore (first and second years of college, respectively), and $87.1 \%$ had socioeconomic level $B$ or $C$, with a mean family income of $R \$ 2,205.00$ regardless of gender.

The median fruit and vegetable intake was 2.0 servings per day regardless of gender. On the other hand, the psychosocial factors parental influence and perceived barriers differed significantly by gender. For the other constructs the $p$-values ranged from 0.06 and 0.20 . Males had higher mean time spent on physical activity than females. Table 1 provides more information.

The fruit and vegetable intake, physical activity, and psychosocial factor correlation matrices indicated that most variables were correlated but had no collinearity $(r>0.80)$ regardless of gender. In males only friends' support and perceived barriers for behavior change were not correlated with fruit and vegetable intake. 
Only three correlations between the psychosocial factors were not significant (Table 2).

In women all constructs correlated with each other and fruit and vegetable intake. Only physical activity did not correlate with friends' influence and perceived barriers (Table 3).

Multiple linear regression indicated that both the male $(F=29.13, p=0.000)$ and female $(F=19.35, p=0.000)$ models were significant, so they are little likely to be random. Behavior change strategy, self-efficacy, friends' influence, and physical activity explained $39 \%$ of the fruit and vegetable intake variance in males (Table 4).

In women the final explanatory model consisted of behavior change strategy, selfefficacy, perceived barrier, and physical activity, which explained $26 \%$ of the fruit and vegetable intake variance (Table 5). In men friends' support, which was not correlated, explained $2 \%$ of the variance when adjusted in the regression model. On the other hand, behavior change strategy, which had the highest correlation with fruit and vegetable intake, continued to be the main predictor, explaining $31 \%$ of the variance. In the regression model for women, friends' and parental support, and perceived facilitators in decision making lost significance. Meanwhile, self-efficacy was the main predictor, explaining $13 \%$ of the variance.

The $b$ intercept indicated that for each unit increase of physical activity (in minutes per day) men and women would increase their fruit and

Table 1. Descriptive values, $F$ value, and significance of fruit and vegetable intake, psychosocial factors, and physical activity in college students $(n=717)$.

\begin{tabular}{|c|c|c|c|c|c|c|}
\hline \multirow{2}{*}{ Variables } & \multicolumn{2}{|c|}{ Men } & \multicolumn{2}{|c|}{ Women } & \multirow{2}{*}{$F$} & \multirow{2}{*}{$p^{*}$} \\
\hline & $\mathrm{M}$ & SD & $\mathrm{M}$ & SD & & \\
\hline Fruits and vegetables (servings) & 2.0 & $0-9$ & 2.0 & $0-8$ & 1.89 & 0.17 \\
\hline Change strategy (15-75) & 37.3 & 13.8 & 39.2 & 13.5 & 3.56 & 0.06 \\
\hline Self-efficacy (7-35) & 21.9 & 6.8 & 22.8 & 6.5 & 3.04 & 0.08 \\
\hline Parental support (4-20) & 9.2 & 4.0 & 9.9 & 4.3 & 4.20 & 0.04 \\
\hline Friends' support (3-15) & 4.6 & 2.2 & 8.9 & 3.3 & 3.45 & 0.06 \\
\hline Perceived barriers (5-25) & 9.4 & 3.8 & 19.2 & 4.3 & 10.40 & $<0.01$ \\
\hline Perceived facilitators (5-25) & 18.1 & 4.9 & 4.8 & 2.3 & 1.64 & 0.20 \\
\hline Physical activity (minutes/week) & 164.0 & 117.9 & 111.6 & 99.0 & 24.80 & $<0.01$ \\
\hline
\end{tabular}

Note: *Analysis of variance; median, maximum, and minimum fruit and vegetable intake.

M: Mean; SD: Standard Deviation.

Table 2. Correlation matrix between fruit and vegetable intake, physical activity, and psychosocial factors in male college students $(n=316)$.

\begin{tabular}{|c|c|c|c|c|c|c|c|c|}
\hline Variables & $\mathrm{FVI}$ & CS & SE & PS & FS & PB & PF & PA \\
\hline FVI & 1.00 & & & & & & & \\
\hline$C S$ & $0.55^{*}$ & 1.00 & & & & & & \\
\hline SE & $0.50^{*}$ & $0.65^{*}$ & 1.00 & & & & & \\
\hline PS & $0.26^{*}$ & $0.44^{*}$ & $0.47^{*}$ & -1.00 & & & & \\
\hline FS & 0.05 & $0.26^{*}$ & $0.43^{*}$ & $-0.06^{*}$ & -1.00 & & & \\
\hline PB & -0.05 & -0.04 & $-0.10^{*}$ & $0.15^{*}$ & -0.07 & 1.00 & & \\
\hline PF & $0.21^{*}$ & $0.44^{*}$ & $0.41^{*}$ & $0.35^{*}$ & $0.15^{*}$ & -0.01 & 1.00 & \\
\hline PA & $0.27^{*}$ & $0.18^{*}$ & $0.15^{*}$ & 0.07 & $0.13^{*}$ & $0.11^{*}$ & 0.08 & 1.00 \\
\hline
\end{tabular}

Note: ${ }^{*} p<0.05$.

FVI: Fruit and Vegetable Intake; CS: Change Strategy; SE: Self-Efficacy; PS: Parental Support; FS: Friends' Support; PB: Perceived Barriers; PF: Perceived Facilitators; PA: Physical Activity. 
vegetable intake by 0.004 and 0.003 servings, respectively. Thus, fruit and vegetable intake would increase by one serving if men and women increased their moderate to intense physical activity by 35 minutes and 47 minutes per day, respectively.

Table 3. Correlation matrix between fruit and vegetable intake, physical activity, and psychosocial factors in female college students $(n=401)$.

\begin{tabular}{|c|c|c|c|c|c|c|c|c|}
\hline Variables & $\mathrm{FVI}$ & CS & SE & PS & FS & PB & PF & PA \\
\hline $\mathrm{FVI}$ & 1.00 & & & & & & & \\
\hline$C S$ & $0.30^{*}$ & 1.00 & & & & & & \\
\hline SE & $0.35^{*}$ & $0.67^{*}$ & 1.00 & & & & & \\
\hline PS & $0.16^{*}$ & $0.62^{*}$ & $0.55^{*}$ & 1.00 & & & & \\
\hline FS & $0.10^{*}$ & $0.58^{*}$ & $0.46^{*}$ & $0.59^{*}$ & 1.00 & & & \\
\hline PB & $-0.16^{*}$ & $0.39^{*}$ & $0.28^{*}$ & $0.35^{*}$ & $0.46^{*}$ & 1.00 & & \\
\hline PF & $0.09^{*}$ & $0.60^{*}$ & $0.44^{*}$ & $0.45^{*}$ & $0.42^{*}$ & $0.41^{*}$ & 1.00 & \\
\hline PA & $0.23^{*}$ & $0.17^{*}$ & $0.13^{*}$ & $0.09^{*}$ & 0.02 & -0.07 & $0.14^{*}$ & 1.00 \\
\hline
\end{tabular}

Note: ${ }^{*} p<0.05$.

FVI: Fruit and Vegetable Intake; CS: Change Strategy; SE: Self-Efficacy; PS: Parental Support; FS: Friends' Support; PB: Perceived Barriers; PF: Perceived Facilitators; PA: Physical Activity.

Table 4. Multiple linear regression of fruit and vegetable intake by male college students and psychosocial factors and physical activity adjusted for the other independent variables.

\begin{tabular}{|c|c|c|c|c|c|}
\hline Variables & $\mathrm{b}$ & $95 \% \mathrm{Cl}(\mathrm{b})$ & $\beta$ & $p^{*}$ & $R^{2}$ \\
\hline Constant & -0.807 & & & & \\
\hline Change strategy & 0.060 & $0.04-0.08$ & 0.379 & 0.000 & 0.31 \\
\hline Self-efficacy & 0.095 & $0.05-0.12$ & 0.312 & 0.000 & 0.03 \\
\hline Parental support & 0.026 & $-0.04-0.07$ & 0.051 & 0.362 & - \\
\hline Friends' support & -0.113 & $-0.25--0.07$ & -0.182 & 0.001 & 0.02 \\
\hline Perceived barriers & -0.021 & $-0.06-0.04$ & -0.036 & 0.423 & - \\
\hline Perceived facilitators & -0.041 & $-0.08-0.01$ & -0.092 & 0.072 & - \\
\hline Physical activity (minutes/day) & 0.004 & 0.003-0.005 & 0.190 & 0.000 & 0.03 \\
\hline Explained variance & & & & & $39 \%$ \\
\hline
\end{tabular}

Note: ${ }^{*}$ Analysis adjusted for all social, demographic, economic, and institutional variables. $F=29.13$ and $p=0.000$.

95\% Cl: 95\% Confidence Interval; $R^{2}$ : Determination coefficient.

Table 5. Multiple linear regression of fruit and vegetable intake by female college students and psychosocial factors and physical activity adjusted for the other independent variables.

\begin{tabular}{|c|c|c|c|c|c|}
\hline Variables & $b$ & $95 \% \mathrm{Cl}(\mathrm{b})$ & $\beta$ & $p^{*}$ & $R^{2}$ \\
\hline Constant & -0.56 & & & & \\
\hline Change strategy & 0.040 & $-0.02-0.06$ & 0.286 & 0.000 & 0.03 \\
\hline Self-efficacy & 0.085 & $0.06-0.13$ & 0.293 & 0.000 & 0.13 \\
\hline Parental support & -0.011 & $-006-0.05$ & -0.025 & 0.690 & - \\
\hline Friends' support & -0.025 & $-0.10-0.08$ & -0.047 & 0.430 & - \\
\hline Perceived barriers & -0.131 & $-0.14--0.02$ & -0.285 & 0.000 & 0.08 \\
\hline Perceived facilitators & -0.034 & $-0.06-0.04$ & -0.076 & 0.180 & - \\
\hline Physical activity (minutes/day) & 0.003 & $0.002-0.004$ & 0.132 & 0.004 & 0.02 \\
\hline Variância explicada & & & & & $26 \%$ \\
\hline
\end{tabular}

Note: ${ }^{*}$ Analysis adjusted for all social, demographic, economic, and institutional variables. $F=19.35$ and $p=0.000$.

95\% Cl: 95\% Confidence Interval; $R^{2}$ : Determination coefficient. 


\section{DISCUSSION}

The objective of the present article was to verify whether psychosocial factors and physical activity are predictors of fruit and vegetable intake in college students. The procedure and sample size were representative, so the prediction models for males and females was estimated, calculating the $R^{2}$ of each construct, the global $R^{2}$, and the $\beta$ values.

In general lines the complexity to establish fruit and vegetable intake was reflected by the variance explained by the prediction models. Even though the number of fruit and vegetable servings did not vary by gender, the variance explained in the model for males was higher than that explained in the model for females (39\% versus $26 \%$ ). In a review Guillaumie et al. ${ }^{8}$, found a variation in the $R^{2}$ values for the prediction models of 0.06 and 0.61 , but in the global aggregate analysis, the explained variance was $23 \%$. The aspects chosen to explain the differences were: a) construct validation; b) sample characteristics; c) prospective and cross-sectional designs, and d) theoretical models ${ }^{8}$. Studies with psychometric properties with $\alpha \geq 0.60$, a homogeneous sample, and prospective designs using the social cognitive theory or theory of planned behavior had more consistent models than studies with psychometric properties with $\alpha<0.6$, a heterogeneous sample, and cross-sectional designs using constructs of two or more theories.

Considering models based on the social cognitive theory, the observed value was $41 \%$, while the models based on multiple theories had a value of $16 \%$. Prospective studies presented an $R^{2}$ of 0.51 , while cross-sectional studies had an $R^{2}$ of 0.18 . If on the one hand the present study used two integrated theoretical models and a cross-sectional design, on the other hand, the psychometric indicators of the instrument and the homogeneous sample were important factors for this finding, especially construct validity, since other validation and intervention studies were already referencing the instrument 12,13,19,24.
In relation to the explained partial variance and the $\beta$ value, the difference is even more variable and in some aspects, diverging, than those of other studies. Self-efficacy is a strong predictor of fruit and vegetable intake regardless of the methodological aspects of the studies and the behavior change theories used ${ }^{7}$. The review by Shaikh et al. ${ }^{7}$, found $\beta$ values of $0.02-0.38$, also considered an important factor in intervention studies. The present study found values of 0.31 and 0.29 for men and women, respectively. The review included studies with heterogeneous samples, which may explain the difference, and only two studies included college students. In a cross-sectional study, Chung \& Hoerr ${ }^{27}$, found a $\beta$ of 0.08 for men and 0.09 for women for fruit intake. However, in a prospective study, Kellar \& Abraham $^{28}$, found a $\beta$ of 0.31 , indicating a strong predictor. This evidence was confirmed in college students by Franko et al. ${ }^{29}$.

Parental and friends' support should be a predictor with positive influence, since crosssectional and prospective studies have found that social support is a strong predictor $(\beta=0.10-0.18)^{8}$. However, in men friends' support was a predictor with negative influence (-0.18). College students adopt self-affirmation behaviors to fit in, such as alcohol intake, smoking, drug use, and sex ${ }^{10}$. Parental support was not significant in neither of the two models perhaps because at this life stage, parental influence is not a determinant for some students, unlike adolescence and childhood.

Studies where social support was a strong predictor of fruit and vegetable intake were generally conducted in a specific social context. For example, in the studies by Resnicow et al. ${ }^{30}$, and Fuemmeler et al. ${ }^{31}$, individuals' perception may have been influenced by the attempt to fit in, since the studies were conducted in a church. On the other hand, in intervention studies social support is a determinant of behavior change ${ }^{32}$, also referenced by social theories ${ }^{6}$.

In the present study, perceived facilitators unexpectedly had an insignificant negative influence. Low fruit and vegetable intake may be 
influenced by students' perception, since the issues that compose this construct may become real barriers given that fruit and vegetable intake is well below the recommended intake and demotivation may be high. Perceived barriers were significant only in the model for women ( $\beta$ of -0.13). These findings are similar to those found by a systematic review with adults: of six studies included in the review, five found this association with $\beta$ variation of -0.06 and $-0.16^{7}$.

Other two variables had important results. Behavior change strategy and physical activity were significant predictors of fruit and vegetable intake in men and women. In men the aspect of thinking strategies and change actions presented a variance of $31 \%$ of the model and a $\beta$ of 0.37 . In women the values were lower but significant (3\% of the model and $\beta$ of 0.29 ).

Regarding physical activity, cluster analyses have indicated that these health behaviors tend to coexist regardless of age ${ }^{33,34}$. In Brazil Figueiredo et al. ${ }^{20}$, found a $\beta$ of $0.31(p=0.001)$ for the influence of leisure-time physical activity on fruit and vegetable intake. In the present study the standardized $\beta$ values were 0.19 and 0.13 for men and women, respectively. However, the present study measured the time spent on moderate and intense physical activities regardless of context.

The fact that more moderate or intense physical activity increases fruit and vegetable intake is an important but underexplored result in this transition from adolescence to adulthood. This hypothesis should be tested by prospective studies as a higher fruit and vegetable intake seems to predict higher physical activity in college students, but the opposite seems to be an important relationship that needs testing.

The strengths of the present study include the methodological procedures: a) use of a theory with validated constructs; b) representative and homogeneous sample in relation to social, demographic, and economic determinants, which did not occur in the other studies, and c) use of another health behavior (physical activity) as predictor. The study has some limitations: a) extrapolation of the results to other Brazilian students and/or young adults, and b) self-reported behavior (physical activity and fruit and vegetable intake), even though data were collected by interview, which reduces error.

Two actions are suggested. Regarding the implications of the results, we propose an integrated behavioral intervention to promote physical activity and fruit and vegetable intake, with education actions and provision of physical activity. The first action would aim to support selfmanagement of fruit and vegetable intake through knowledge, proposition of strategies for behavior change and maintenance, and self-efficacy. The second action would aim to increase students' social integration and test the influence of physical activity in an intervention study. Studies on the complexity of health behaviors should include specific life stages, especially prospective studies that aim to verify the influence of each psychosocial factor on this process.

\section{COLABORADORES}

TASSITANO RM designed the study, performed the data analysis, and wrote the study report. MOTA J and TENÓRIO MCM critically reviewed the manuscript. MARTINS CML, CABRAL PC, and SILVA GAP reviewed the manuscript, contributed to data interpretation and discussion of results. The final paper version was approved by all authors.

\section{REFERENCES}

1. World Health Organization. Diet, nutrition and the prevention of chronic diseases. Report of a Joint WHO/FAO Expert Consultation. WHO Technical Report Series, n 916. Geneva: WHO; 2003.

2. World Health Organization. Global health risks: Mortality and burden of disease attributable to selected major risks. Genebra: WHO; 2009.

3. Instituto Brasileiro de Geografia e Estatística. Pesquisa de orçamentos familiares 2008-2009: análise do consumo alimentar pessoal no Brasil. Rio de Janeiro: IBGE; 2011.

4. Story M, Neumark-Sztainer D, French S. Individual and environmental influences on adolescent eating 
behaviors. J Am Diet Assoc. 2002; 102(Suppl. 3): S40-S51. http://dx.doi.org/10.1016/S0002-8223 (02)90421-9

5. Kamphuis CBM, Giskes K, Brujin GJ, Wendel-Vos W, Brug J, Van Lenthe FJV. Environmental determinants of fruit and vegetable consumption among adults: A systematic review. Br J Nutr. 2006; 96(4):620-35.

6. Glanz K, Rimer BK, Viswanath K. Health behavior and health education: Theory, research, and practice. $4^{\text {th }}$ ed. San Francisco (CA): John Wiley \& Sons; 2008.

7. Shaikh AR, Yaroch AL, Nebeling L, Yeh MC, Resnicow K. Psychosocial predictors of fruit and vegetable consumption in adults: A review of the literature. Am J Prev Med. 2008; 34:535-43. http:// dx.doi.org/10.1016/j.amepre.2007.12.028

8. Guillaumie L, Godin G, Vézina-Im LD. Psychosocial determinants of fruit and vegetable intake in adult population: A systematic review. Int J Behav Nutr Phys Act. 2010; 7:12. http://dx.doi.org/10.1186/ 1479-5868-7-12

9. Baranowski T, Cullen KW, Baranowski J. Psychosocial correlates of dietary intake: Advancing dietary intervention. Annu Rev Nutr. 1999; 19:17-40.

10. Lori AJ, Scott-Sheldon E, Carey KB, Carey MP. Health behavior and college students: Does Greek affiliation matter? J Behav Med. 2008; 31(1):61-70. http://dx. doi.org/10.1007/s10865-007-9136-1

11. Prochaska JO. Multiple Health Behavior Research represents the future of preventive medicine. Prev Med. 2008; 46(3):281-5. http://dx.doi.org/10.10 16/j.ypmed.2008.01.015

12. Jago R, Nicklas T, Yang SJ, Baranowski T, Zakeri I, Berenson GS. Physical activity and health enhancing dietary behaviors in young adults: Bogalusa Heart Study. Prev Med. 2005; 41(1):194-202. http://dx. doi.org/10.1016/j.ypmed.2004.09.045

13. Patrick K, Calfas KJ, Norman GJ, Zabinski MF, Sallis JF, Rupp J, et al. Randomized controlled trial of a primary care and home-based intervention for physical activity and nutrition behaviors: PACE+ for adolescents. Arch Pediatr Adolesc Med. 2006; 160(2):128-36.

14. Calfas KJ, Sallis JF, Zabinski MF, Wilfley DE, Rupp J, Prochaska JJ, et al. Preliminary evaluation of a multicomponent program for nutrition and physical activity change in primary care: PACE+ for adults. Prev Med. 2002; 34(2):153-61. http://dx.doi.org/ 10.1006/pmed.2001.0964

15. World Health Organization. Global Strategy on diet, physical activity and health. Geneva: WHO; 2004.

16. World Health Organization. Interventions on diet and physical activity: What works: Summary report. Geneva: WHO; 2009.
17. Bandura A. Human agency in social cognitive theory. Am Psychol. 1989; 44(9):1175-84.

18. Prochaska JO, Velicer WF. The Transtheoretical model of health behavior change. Am J Health Promot. 1997; 12(1):38-48. http://dx.doi.org/10. 4278/0890-1171-12.1.38

19. Hagler AS, Norman GJ, Radick LR, Calfas KJ, Sallis JF. Comparability and reliability of paper and computer based measures of psychosocial construtors for adolescent fruit and vegetable and dietary fat intake. J Am Diet Assoc. 2005; 105:1758-64.

20. Figueiredo ICR, Jaime PC, Monteiro CA. Fatores associados ao consumo de frutas, legumes e verduras em adultos da cidade de São Paulo. Rev Saúde Pública. 2008; 42(5):777-85. http://dx.doi.org/10. 1590/S0034-89102008005000049

21. Faul F, Erdfelder E, Buchner A, Langa AG. Statistical power analyses using $G *$ Power 3.1: Tests for correlation and regression analyses. Behav Res Methods. 2009; 41(4):1149-60. http://dx.doi.org/ 10.3758/BRM.41.4.1149

22. Slater B, Philippi ST, Fisberg RM, Latorre MR. Validation of a semi-quantitative adoelscent food frequency questionnaire applied at a public school in São Paulo. Eur J Clin Nutr. 2003; 57(5):629-35. http://dx.doi.org/10.1038/sj.ejcn.1601588

23. Kim DJ, Holowaty EJ. Brief, validated survey instruments for the measurement of fruit and vegetable intakes in adults: A review. Prev Med. 2003; 36(4):440-7. http://dx.doi.org/10.1016/S0 091-7435(02)00040-3

24. Tassitano RM, Cabral PC, Silva GAP. Validação de escalas psicossociais para mudança do consumo de frutas, legumes e verduras. Cad Saúde Pública. 2014; 30(2):272-82. http://dx.doi.org/10.1590/010 2-311X00153812

25. Kim Y, Park I, Kang M. Convergent validity of the Internacional Physical Activity Questionnaire (IPAQ): Meta-analysis. Public Health Nutr. 2012; 2:1-13. http://dx.doi.org/10.1017/S1368980012002996

26. Associação Brasileira das Empresas de Pesquisa. Critério de classificação econômica Brasil. São Paulo: Abep; 2011 [acesso 2010 ago 26]. Disponível em http://www.anep.org

27. Chung SJ, Hoerr S. Predictors of fruit and vegetable intakes in young adults by gender. Nutr Res. 2005; 25(5):453-63. http://dx.doi.org/10.1016/j. nutres. 2005.03.002

28. Kellar I, Abraham C. Randomized controlled trial of a brief research-based intervention promoting fruit and vegetable consumption. $\mathrm{Br} J$ Health Psychol. 2005; 10(4):543-58. http://dx.doi.org/ $10.1348 / 135910705 \times 42940$ 
29. Franko DL, Cousineau TM, Trant M, Green TC, Rancourt D, Thompson D, et al. Motivation, selfefficacy, physical activity and nutrition in college students: Randomized controlled trial of an internet-based education program. Prev Med. 2008; 47(4):369-77. http://dx.doi.org/10.1016/j. ypmed.2008.06.013

30. Resnicow K, Wallace DC, Jackson A, Digirolamo A, Odom E, Wang $T$, et al. Dietary change through African American churches: Baseline results and program description of the eat for life trial. J Cancer Educ. 2000; 15(3):156-63. http://dx.doi.org/10. 1080/08858190009528685

31. Fuemmeler BF, Mâsse LC, Yaroch AL, Resnicow K, Campbell MK, Carr C, et al. Psychosocial mediation of fruit and vegetable consumption in the body and soul effectiveness trial. Health Psychol. 2006; 25(4):474-83. http://dx.doi.org/10.1037/0278-61 33.25.4.474
32. Mendonça G, Cheng LA, Mélo EN, de Farias Júnior JC. Physical activity and social support in adolescents: A systematic review. Health Educ Res. 2014; 29(5):822-39. http://dx.doi.org/10.1093/her/ cyu017

33. Dumith SC, Muniz LC, Tassitano RM, Hallal PC, Menezes AM. Clustering of risk factors for chronic diseases among adolescents from Southern Brazil. Prev Med. 2012; 54(6):393-6. http://dx.doi.org/10. 1016/j.ypmed.2012.03.014

34. Poortinga $W$. The prevalence and clustering of four major lifestyle risk factors in an English adult population. Prev Med. 2007; 44(2):124-8. http:// dx.doi.org/10.1016/j.ypmed.2006.10.006

Received: March 3, 2015

Final version: October 19, 2015

Approved: November 27, 2015 
